\title{
Inhibition of hydrogen sulfide corrosion of steel by volatile amines
}

\author{
R. V. Kashkovskiy ${ }^{1}$ and Yu. I. Kuznetsov ${ }^{2}$ \\ ${ }^{1}$ GAZPROM VNIIGAZ, POB 130, Moscow, 115583 Russian Federation \\ E-mail: roman.kashkovskiy@gmail.com \\ ${ }^{2}$ A. N. Frumkin Institute of Physical Chemistry and Electrochemistry, Russian Academy \\ of Sciences, Leninskii pr. 31, Moscow, 119071 Russian Federation \\ E-mail: kuznetsov@ipc.rssi.ru
}

\begin{abstract}
The protective effect of amines on steel corrosion under simulated conditions of gas condensate fields are studied. It is shown that primary amines are less effective than secondary and tertiary ones in terms of steel protection, especially in vapor phase. The authors also studied the impact of $C_{\mathrm{H}_{2} \mathrm{~S}}, \mathrm{pH}$, temperature and presence of a hydrocarbon phase on protective effect of chemical compounds considered.
\end{abstract}

Key words: corrosion, hydrogen sulfide, carbon steel, volatile amine.

Received: October 21, 2012.

doi: $\underline{10.17675 / 2305-6894-2012-1-2-117-129}$

\section{Introduction}

Development of oil and gas fields today is complicated by several problems associated with corrosion damage of equipment and pipelines [1-4]. High corrosive effect of sour natural gas is caused by the presence of moisture and acid gases $\left(\mathrm{H}_{2} \mathrm{~S}\right.$ and $\left.\mathrm{CO}_{2}\right) . \mathrm{H}_{2} \mathrm{~S}$ is the most dangerous gas because it stimulates general corrosion and forces steel hydrogenation, which leads to loss of its elastic properties and cracking [5].

Experience of oil and gas equipment operation shows that one of the most effective and advanced methods to prevent corrosion is to use inhibitors. It allows the service life and reliability of equipment to be increased without serious interference in the operation process $[6,7]$.

Contact corrosion inhibitors are widely used for corrosion protection of oil and gas equipment. However, they will have protective effect in vapor phase only provided that they preliminarily form a coating on the surface. But such coatings are not able to recover if their integrity is disturbed, for example, by gas flow. Volatile corrosion inhibitors (VCIs) exhibit this property and are able to penetrate into gaps and slots of complex metallic structures [8]. As opposed to contact inhibitors, they have a sufficient vapor pressure $\left(p_{\mathrm{s}}\right)$ to be volatile, saturate the gas-vapor phase and are adsorbed on the steel surface creating a self-organizing protective layer. However, there is not much information on development 
of new VCIs for steel protection against hydrogen sulfide corrosion (HSC) [9-12]. In view of this, we studied the possibility of steel HSC inhibition by volatile amines and the impact of various media properties on it.

\section{Experimental}

Corrosive behavior of steel was studied on low-carbon (St.3, St.20, 08ps, SV08A) and high-carbon steel samples (70S2KhA). Their composition is given in Table 1. NACE solution $\left(0.5 \% \mathrm{NaCl}, 0.25 \mathrm{~g} / 1 \mathrm{CH}_{3} \mathrm{COOH}, \mathrm{pH} 3.6\right)$ simulated a corrosion medium in a gas condensate field. Tests were performed for different $\mathrm{H}_{2} \mathrm{~S}$ concentrations. $\mathrm{H}_{2} \mathrm{~S}$ content was monitored by standard iodometric titration. In some cases tests were carried out in the presence of a hydrocarbon phase (white spirit); the hydrocarbon-water ratio was 1:10, excess pressure $P_{\mathrm{N}_{2}}=1$ atm.

Table 1. Steel sample composition (mass \%).

\begin{tabular}{cccccccccc}
\hline Steel & C & Mn & Si & P & S & Cr & Ni & Cu & As \\
\hline St.3 & 0.18 & 0.5 & 0.21 & 0.04 & 0.05 & - & - & - & - \\
St.20 & 0.21 & 0.5 & 0.27 & - & - & 0.25 & - & - & - \\
SV08A & 0.1 & 0.47 & 0.03 & 0.03 & 0.03 & 0.12 & 0.25 & - & - \\
08ps & 0.08 & 0.5 & 0.11 & 0.035 & 0.04 & 0.1 & 0.25 & 0.25 & 0.08 \\
70S2KhA & 0.7 & 0.52 & 1.52 & - & - & 0.3 & - & - & - \\
\hline
\end{tabular}

Impact of inhibitors on steel corrosion was studied by gravimetric method on steel plates with the area $(S) 8.4 \mathrm{~cm}^{2}$ and $18 \mathrm{~cm}^{2}$ for St.08ps and St.70C2KhA correspondingly. The samples were weighed on analytical balance with an accuracy of $10^{-6} \mathrm{~g}$. The test duration was from 1.5 to $240 \mathrm{hrs}$. Corrosion rate $(K)$ was evaluated by mass losses $(\Delta m)$, averaged by data on three (liquid phase) and six (gas phase) samples for the given period of time $(\tau)$ :

$$
K=\frac{\Delta m}{S \cdot \tau}
$$

Inhibitor protective effect $(Z)$ was calculated by the formula:

$$
Z(\%)=\frac{K_{0}-K_{\text {in }}}{K_{0}} \cdot 100,
$$

where $K_{0}$ and $K_{\text {in }}$ are the corrosion rates in non-inhibited and inhibited media, respectively.

Corrosion tests were performed in cylindrical glass vessels $280 \times 15 \mathrm{~mm}$ in size with ground-in stoppers $(1.5 \mathrm{~h})$ and in 2 litre plastic vessels at $20 \pm 2{ }^{\circ} \mathrm{C}$. Steel samples were put 
into the vessel in such a manner that one part of them was fully immersed in the corrosive solution, while the other part was in a vapor phase above the solution. $\mathrm{pH}$ before and after the tests was determined by a $\mathrm{pH}$ analyzer.

Tests with wet $\mathrm{H}_{2} \mathrm{~S}$ were carried out in Drexel cells on St.20 samples $\left(S=24.8 \mathrm{~cm}^{2}\right)$ and wire made from SV08A steel $(L=11 \mathrm{~cm})$. Hydrogen sulfide was passed through the cell for 5 hours. Primarily the system was deaerated by nitrogen $(30 \mathrm{~min})$. The cells were half filled with NACE base solution (Fig. 1). VCIs were injected into the liquid phase. Steel samples were put into both liquid and vapor phases above the solution. Tests under increased temperature were performed in the same way, but the cells were put into a water bath with automatic thermal control.

Impact of repeated wetting was studied on a wheel type unit $\left(w=80\right.$ r.p.m, $t=20^{\circ} \mathrm{C}$, $\tau=5 \mathrm{~h}$ ) on St. 3 samples $\left(S=10 \mathrm{~cm}^{2}\right)$. After all the tests, corrosion products were removed by a washing solution containing $880 \mathrm{ml}$ of distilled water, $66 \mathrm{ml}$ of concentrated $\mathrm{H}_{2} \mathrm{SO}_{4}$, $100 \mathrm{~g}$ of citric acid, and $10 \mathrm{~g}$ of thiourea.

Plasticity of SV08A steel was estimated with an NG-1-3M unit by the number of sample bends $(L=11 \mathrm{~cm})$ until it destruction in the initial state $\left(n_{0}\right)$ and after testing in the inhibited solution $(n)$. Residual plasticity of steel $(P, \%)$ was determined by the formula:

$$
P=\left(n / n_{0}\right) \cdot 100 \%
$$

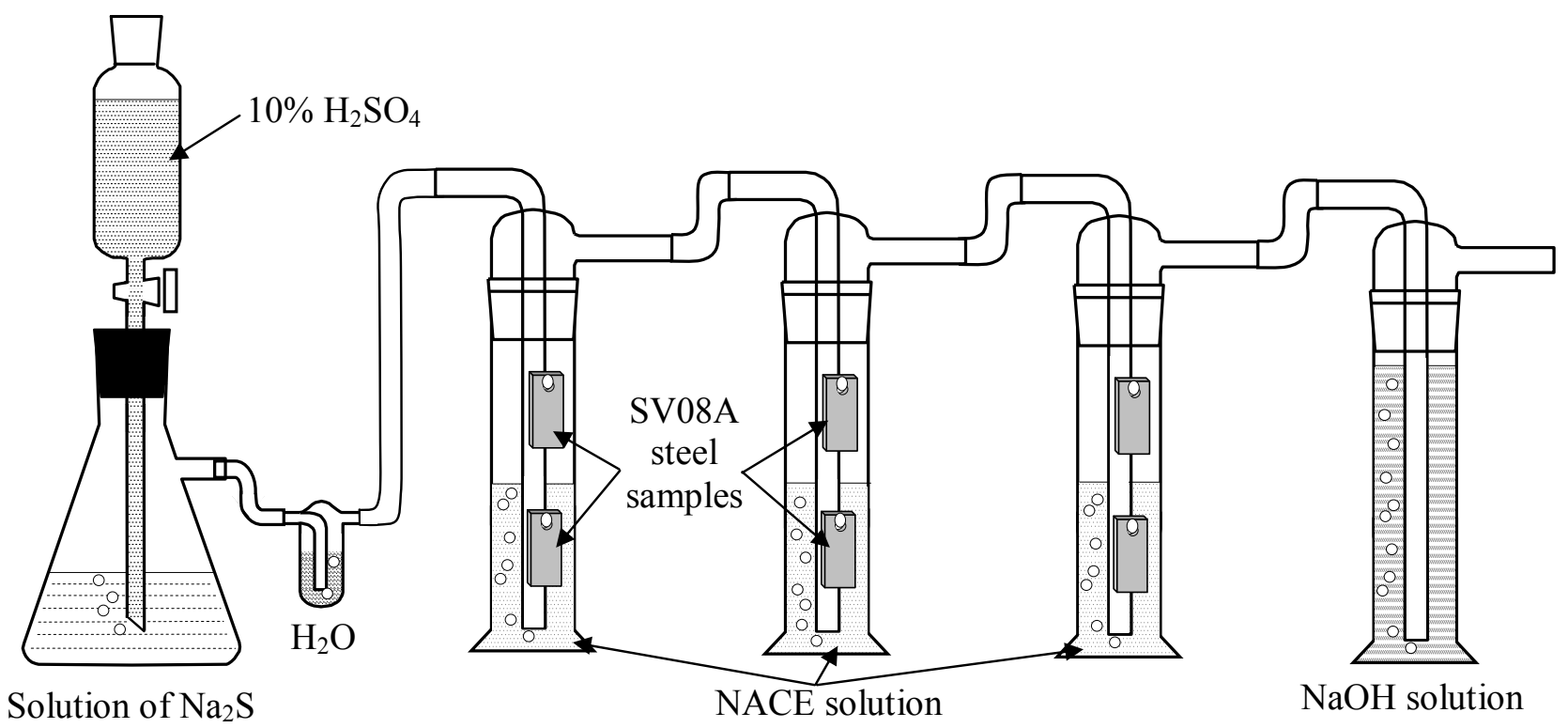

Fig. 1. Chart of experiment under steady wet $\mathrm{H}_{2} \mathrm{~S}$ flow conditions. 


\section{Results and discussion}

\section{Impact of VCIs Chemical Structure on Their Inhibiting Properties}

It is known [7, 9-12] that steel HSC inhibitors are usually represented by nitrogencontaining organic compounds. In order to be a VCI they should have a vapor pressure not less than $10^{-6} \mathrm{mmHg}$ [8]. That is why we studied aliphatic and aromatic amines as HSC volatile inhibitors. Their $p_{S}$ values were calculated by the method proposed in $[13,14]$. This method is based on the linear energy relationship principle.

First of all we studied the ability of considered compounds to protect steel against HSC in the liquid phase in short-term $(1.5 \mathrm{~h})$ corrosion tests in NACE solution saturated by $\mathrm{H}_{2} \mathrm{~S}(2 \mathrm{~g} / \mathrm{l})$ (Tables 2-4). Corrosion rate of high-strength 70S2KhA steel in this media without inhibitor was estimated at $0.856 \mathrm{~g} /\left(\mathrm{m}^{2} \cdot \mathrm{h}\right)$.

Table 2. Protective HSC effects of primary amines (steel 08ps and 70S2KhA) in vapor gas (numerator) and liquid (denominator) phases after $1.5 \mathrm{~h}$ and $240 \mathrm{~h}$ tests in NACE solution saturated by $2 \mathrm{~g} / 1 \mathrm{H}_{2} \mathrm{~S}$.

\begin{tabular}{|c|c|c|c|c|c|c|c|}
\hline \multirow[b]{2}{*}{ Substance } & \multirow[b]{2}{*}{$\begin{array}{c}M, \\
\mathrm{~g} / \mathrm{mol}\end{array}$} & \multirow[b]{2}{*}{$\lg P$} & \multirow[b]{2}{*}{$\begin{array}{c}p_{\mathrm{s}} \\
\mathrm{mmHg}\end{array}$} & \multirow{2}{*}{$\begin{array}{c}\tau=1.5 \mathrm{~h} \\
C_{\text {in }}=1 \mathrm{~g} / 1 \\
\text { St.70S2KhA } \\
Z_{\text {liq }} \%\end{array}$} & \multicolumn{3}{|c|}{$\tau=240 \mathrm{~h}$} \\
\hline & & & & & $C_{\text {in }}, \mathrm{g} / 1$ & $\begin{array}{c}\text { St. 08ps } \\
Z, \%\end{array}$ & $\begin{array}{c}\text { St.70S2KhA } \\
Z, \%\end{array}$ \\
\hline \multicolumn{8}{|c|}{ PRIMARY AMINES } \\
\hline Allylamine (AA) & 57 & -0.12 & 57.8 & 95.4 & - & - & - \\
\hline tert-Butylamine & 73 & 0.67 & 77.2 & 52.4 & - & - & - \\
\hline Cyclohexylamine & 99 & 1.52 & 3.2 & 82.6 & 3.0 & $\frac{12.0}{83.0}$ & \\
\hline \multirow{2}{*}{ Benzylamine (BA) } & \multirow{2}{*}{107} & \multirow{2}{*}{1.44} & \multirow{2}{*}{0.5} & \multirow{2}{*}{88.2} & 1.0 & $\frac{20.0}{90.3}$ & \\
\hline & & & & & 3.0 & $\frac{23.0}{87.3}$ & \\
\hline Heptylamine & 115 & 2.59 & 1.1 & 94.0 & 2.0 & $\frac{50.0}{73.2}$ & $\frac{54.1}{99.0}$ \\
\hline $\begin{array}{c}\text { Mixture of primary } \\
\text { amines } \mathrm{C}_{10}-\mathrm{C}_{13} \text { (MPA) }\end{array}$ & $\sim 180$ & 5.13 & 0.013 & 95.7 & 1.0 & $\frac{45.6}{94.4}$ & $\frac{80.5}{98.0}$ \\
\hline
\end{tabular}

As expected, protective effect of primary amines (Table 2) increases along with the growth of hydrophobic properties of their hydrocarbon radical, and consequently the surface activity of the inhibitor itself. Allylamine is the only exception. It has hydrophilic properties $(\lg P<0)^{1}$ and ensures high-grade protection. It seems that due to multiple bond

\footnotetext{
${ }^{1}$ Here $P$ is the distribution ratio of a compound in the system of two immiscible liquids, octanol-water. It helps to identify its hydrophobicity value, which increases along with $\lg P$ [15].
} 
in the allyl radical this amine reacts with hydrogen sulfide and generates surfactants that are adsorbed on steel better that the amine itself.

Benzene ring in the primary amine reduces inhibitor's protective effect. Thus, benzylamine and heptylamine have the same number of carbon atoms $\left(\mathrm{C}_{7}\right)$ and almost the same molecular mass. However in the liquid phase aliphatic amine demonstrates the better corrosion protection properties. This can be explained by the fact that heptyl is more hydrophobic than benzyl. tert-Butylamine provides the lowest steel protection among the studied primary amines $(Z=52.4 \%)$. This can be explained by the branched tert-radical that creates space limits for inhibitor adsorption.

If samples are exposed for 10 days, steel corrosion rate in the liquid phase will decrease to $K=0.28 \mathrm{~g} /\left(\mathrm{m}^{2} \cdot \mathrm{h}\right)$. This is caused by formation of a corrosion film (ferric sulfides) that has some protective properties. Effectiveness of steel protection against HSC by amines in the liquid phase does not differ much as compared to short term tests $( \pm 2 \%)$. Even if the inhibitor concentration $\left(C_{\text {in }}\right)$ increases threefold (benzylamine and cyclohexylamine), the situation remains similar.

Corrosion rate for 10 day exposure in vapor gas phase is slightly higher: $K=$ $0.35 \mathrm{~g} /\left(\mathrm{m}^{2} \cdot \mathrm{h}\right)$, and $Z$ value for primary amines is by $2-4$ times lower than in a liquid phase. The mixture of primary amines $\mathrm{C}_{10}-\mathrm{C}_{13}$ (MPA) is the best inhibitor in this case. It provides less than $50 \%$ corrosion protection for $08 \mathrm{ps}$ steel and $80.5 \%$ protection for 70S2KhA steel. Unfortunately, MPA injection into solution causes strong solution foaming even for $C_{\text {in }}<1.0 \mathrm{~g} / 1$, which restricts application of this VCI. In both short and long tests heptylamine demonstrated lower protection properties in the liquid phase as compared to MPA $\left(Z_{\text {gas }}<60 \%\right)$. Other primary amines were even less effective in short tests (as compared to heptylamine), that is why they were not studied further.

Increase in steel protection along with the growth of molecular mass is typical of secondary amines as well (Table 3 ). All studied secondary amines demonstrated good corrosion protection during short-term tests $(Z>89 \%)$.

As for long-term tests $(240 \mathrm{~h})$ protective effect of secondary amines increased in the liquid phase $(Z \geq 95 \%)$. This can be explained by the fact that inhibitors form a stronger protection film with time. Diisoamylamine with the highest hydrophobicity $(\lg P=3.83)$ is effective in both phases. Even at $C_{\text {in }}=0.5 \mathrm{~g} / 1$, it ensures good protection of $08 \mathrm{ps}$ steel in gas vapor phase $(Z=81.7 \%)$, and it almost stops the corrosion at $2 \mathrm{~g} / \mathrm{l}(Z=99.1 \%)$.

During long-term tests in the liquid phase, benzylcyclohexylamine (BCHA) dramatically decreases the HSC even at $0.1 \mathrm{~g} / 1$, and at $C_{\text {in }} \geq 0.5 \mathrm{~g} / 1$ corrosion process almost stops. However, BCHA is less effective in the gas vapor phase $(Z<60 \%)$. It demonstrates lower HSC inhibition properties than diisoamylamine and dibutylamine. This is probably because of its lower volatility as compared to these amines (Table 3 ). A further increase in $C_{\text {in }}$ caused sedimentation, and this did not allow to study cases with more concentrations of the inhibitor. 
Table 3. Protective HSC effects of secondary amines (steel 08ps and 70S2KhA) in vapor gas (numerator) and liquid (denominator) phases after 1.5- and 240-hour tests in NACE solution saturated by $2 \mathrm{~g} / 1 \mathrm{H}_{2} \mathrm{~S}$.

\begin{tabular}{|c|c|c|c|c|c|c|c|}
\hline \multirow[b]{2}{*}{ Compound } & \multirow{2}{*}{$\begin{array}{l}M, \\
\mathrm{~g} / \mathrm{mol}\end{array}$} & \multirow[b]{2}{*}{$\lg P$} & \multirow{2}{*}{$\underset{\mathbf{m m H g}}{p_{\mathrm{s}},}$} & \multirow{2}{*}{$\begin{array}{c}\tau=1.5 \mathrm{~h} \\
C_{\text {in }}=1 \mathrm{~g} / \mathrm{l} \\
\text { St.70S2KhA } \\
Z_{\text {liq }}, \%\end{array}$} & \multicolumn{3}{|c|}{$\tau=240 \mathrm{~h}$} \\
\hline & & & & & $\begin{array}{c}C_{\text {in }}, \\
\mathrm{g} / \mathbf{l}\end{array}$ & $\begin{array}{l}\text { St. 08ps } \\
Z, \%\end{array}$ & $\begin{array}{c}\text { St.70S2KhA } \\
Z, \%\end{array}$ \\
\hline \multicolumn{8}{|c|}{ SECONDARY AMINES } \\
\hline Dipropylamine & 101 & 1.67 & 12.3 & 89.1 & - & - & - \\
\hline \multirow{3}{*}{ Diisoamylamine (DIAA) } & \multirow{3}{*}{157} & \multirow{3}{*}{3.83} & \multirow{3}{*}{0.3} & \multirow{3}{*}{90.6} & 0.5 & $\frac{81.7}{97.3}$ & $\frac{70.2}{76.1}$ \\
\hline & & & & & 1.0 & $\frac{82.5}{99.3}$ & $\frac{89.0}{91.3}$ \\
\hline & & & & & 2.0 & $\frac{99.1}{99.7}$ & $\frac{92.1}{96.1}$ \\
\hline \multirow{4}{*}{ Dibutylamine (DBA) } & \multirow{4}{*}{129} & \multirow{4}{*}{2.75} & \multirow{4}{*}{1.2} & \multirow{4}{*}{90.2} & 1.0 & $\frac{68.3}{98.4}$ & $\frac{98.5}{98.9}$ \\
\hline & & & & & 1.5 & $\frac{80.5}{99.3}$ & $\frac{93.5}{99.1}$ \\
\hline & & & & & 2.0 & $\frac{73.7}{94.3}$ & $\frac{96.8}{98.8}$ \\
\hline & & & & & 3.0 & $\frac{54.3}{94.8}$ & $\frac{44.3}{98.1}$ \\
\hline \multirow{3}{*}{$\begin{array}{c}\text { Benzylcyclohexylamine } \\
\text { (BCHA) }\end{array}$} & \multirow{3}{*}{189} & \multirow{3}{*}{3.38} & \multirow{3}{*}{$3 \cdot 10^{-3}$} & \multirow{3}{*}{99.4} & 0.1 & $\frac{12.0}{98.2}$ & $\frac{6.0}{98.4}$ \\
\hline & & & & & 0.5 & $\frac{24.8}{99.6}$ & $\frac{17.0}{99.9}$ \\
\hline & & & & & 1.0 & $\frac{58.5}{99.7}$ & $\frac{28.4}{99.9}$ \\
\hline
\end{tabular}

As for tertiary amines (Table 4), the more is their molecular mass, the better protective effect they provide for different time periods of sample exposure. Even in shortterm tests dimetylbenzylamine (DMBA), the less effective tertiary amine, is better than all studied primary and secondary amines in terms of steel protection against HSC. Only BCHA is better that DMBA. Finally, tributylamine demonstrated the best inhibitor properties among all the amines studied. 
Table 4. Protective HSC effects of tertiary amines (steel 08ps and 70S2KhA) in vapor gas (numerator) and liquid (denominator) phases after 1.5- and 240-hour tests in NACE solution saturated by $2 \mathrm{~g} / 1 \mathrm{H}_{2} \mathrm{~S}$.

\begin{tabular}{|c|c|c|c|c|c|c|c|}
\hline \multirow[b]{2}{*}{ Substance } & \multirow{2}{*}{$\begin{array}{c}M, \\
\text { g/mol }\end{array}$} & \multirow[b]{2}{*}{$\lg P$} & \multirow{2}{*}{$\begin{array}{c}p_{\text {s }} \\
\text { mmHg }\end{array}$} & \multirow{2}{*}{$\begin{array}{c}\tau=1.5 \mathrm{~h} \\
C_{\text {in }}=1 \mathrm{~g} / \mathrm{l} \\
\text { St.70S2KhA } \\
Z_{\text {liq }}, \%\end{array}$} & \multicolumn{3}{|c|}{$\tau=240 \mathrm{~h}$} \\
\hline & & & & & $\begin{array}{l}C_{\text {in }}, \\
\mathrm{g} / \mathrm{l}\end{array}$ & $\begin{array}{l}\text { St. 08ps } \\
Z Z, \%\end{array}$ & $\begin{array}{c}\text { St.70S2KhA } \\
Z, \%\end{array}$ \\
\hline \multicolumn{8}{|c|}{ TERTIARY AMINES } \\
\hline \multirow{4}{*}{ Dimethyloctylamine } & \multirow{4}{*}{157} & \multirow{4}{*}{3.31} & \multirow{4}{*}{0.876} & \multirow{4}{*}{96.8} & 0.5 & $\frac{20.0}{99.3}$ & $\frac{0.0}{97.6}$ \\
\hline & & & & & 1.0 & $\frac{37.0}{97.7}$ & $\frac{0.0}{98.2}$ \\
\hline & & & & & 1.5 & $\frac{40.4}{93.0}$ & $\frac{0.0}{99.2}$ \\
\hline & & & & & 3.0 & $\frac{42.8}{97.5}$ & $\frac{0.0}{99.8}$ \\
\hline \multirow{2}{*}{$\begin{array}{l}\text { Dimethylbenzylamine } \\
\text { (DMBA) }\end{array}$} & \multirow{2}{*}{135} & \multirow{2}{*}{1.56} & \multirow{2}{*}{0.576} & \multirow{2}{*}{95.7} & 1.0 & $\frac{0.0}{95.3}$ & $\frac{0.0}{95.8}$ \\
\hline & & & & & 3.0 & $\frac{43.7}{92.7}$ & $\frac{21.1}{95.9}$ \\
\hline \multirow{5}{*}{ Tributylamine (TBA) } & \multirow{5}{*}{185} & \multirow{5}{*}{4.23} & \multirow{5}{*}{$8 \cdot 10^{-2}$} & \multirow{5}{*}{97.7} & 0.5 & $\frac{73.9}{98.5}$ & $\frac{92.4}{99.2}$ \\
\hline & & & & & 1.0 & $\frac{74.0}{98.3}$ & $\frac{98.7}{99.8}$ \\
\hline & & & & & 2.0 & $\frac{77.7}{99.8}$ & $\frac{96}{100}$ \\
\hline & & & & & 3.0 & $\frac{89.1}{100.0}$ & $\frac{94.2}{100}$ \\
\hline & & & & & 4.0 & $\frac{98.7}{99.9}$ & $\frac{99.7}{100}$ \\
\hline
\end{tabular}

In the gas phase, the protective effect increases in the following series: DMBA $<$ dimetyloctylamine $<$ tributylamine. The latter provides a high level of steel protection against HSC in vapor gas phase and is inferior only to diisoamylamine. This means that its volatility is sufficient to form a protective layer. That is why at $C_{\mathrm{in}} \geq 2.0 \mathrm{~g} / 1$, tributylamine can ensure steel protection in $\mathrm{H}_{2} \mathrm{~S}$-containing media. However, it has some drawbacks. At such $C_{\text {in }}$, sedimentation in the solution is inevitable. 


\section{Impact of Corrosive Medium Composition on HSC Process and its Inhibition}

As it was shown above, secondary and tertiary amines are much better than primary ones in terms of ability to protect steel from HSC in vapors. That is why we have chosen two VCIs (secondary - SA and tertiary - TA) to study inhibitor protection in the gas phase (Table 5), as they are able to ensure effective protection of steel against steel corrosion in $\mathrm{H}_{2} \mathrm{~S}$-containing media $(Z>90 \%)$.

As it was mentioned earlier [16], $C_{\mathrm{H}_{2} \mathrm{~S}}$ determines the protective properties of HSC inhibitors. Indeed, without VCI the $K$ value of $08 \mathrm{ps}$ steel appropriately increased along with $C_{\mathrm{H}_{2} \mathrm{~S}}$ both in liquid $\left(0.071,0.098,0.23 \mathrm{~g} /\left(\mathrm{m}^{2} \cdot \mathrm{h}\right)\right)$ and in vapor phases $(0.145,0.155$, $\left.0.455 \mathrm{~g} /\left(\mathrm{m}^{2} \cdot \mathrm{h}\right)\right)$ for $C_{\mathrm{H}_{2} \mathrm{~S}}=0.5,1.0$ and $2.0 \mathrm{~g} / \mathrm{l}$, respectively. The same situation happened for 70S2KhA high strength steel: $K_{\text {liq }}=0.162,0.41,0.43 \mathrm{~g} /\left(\mathrm{m}^{2} \cdot \mathrm{h}\right), K_{\text {gas }}=0.118,0.161$, $0.417 \mathrm{~g} /\left(\mathrm{m}^{2} \cdot \mathrm{h}\right)$. The more is the $C_{\mathrm{H}_{2} \mathrm{~S}}$ value, the more effective are the amines. This is most evident in gas vapor phase. For example, at $C_{\mathrm{in}}=C_{\mathrm{H}_{2} \mathrm{~S}}=2.0 \mathrm{~g} / 1 \mathrm{TA}$, the protection efficiency for $08 \mathrm{ps}$ and $70 \mathrm{~S} 2 \mathrm{KhA}$ steels is $Z_{\text {gas }}=95.7$ and $93.4 \%$, respectively, and 94.2 and $98.9 \%$ for SA. At the same $C_{\text {in }}$ and $C_{\mathrm{H}_{2} \mathrm{~S}}=1.0 \mathrm{~g} / 1$, TA efficiency decreases to $Z_{\mathrm{gas}}=58$ and $42.5 \%$ and that of SA to $Z_{\text {gas }}=63.4$ and $66.6 \%$ (Table 5). If $C_{\mathrm{H}_{2} \mathrm{~S}}$ decreases to $0.5 \mathrm{~g} / 1$, $Z_{\text {gas }}$ for SA remains at $60-75 \%$, whereas TA stimulates corrosion $\left(Z_{\mathrm{gas}}<0\right)$. As expected, a decrease in $C_{\text {in }}$ by half caused a significant reduction in protection efficiency of amines, $Z_{\text {gas }}<0$ for $C_{\mathrm{H}_{2} \mathrm{~S}}=0.5-1.0 \mathrm{~g} / 1$.

Such behavior of amines upon $C_{\mathrm{H}_{2} \mathrm{~S}}$ decrease is probably associated with reduction of $\mathrm{H}_{2} \mathrm{~S}$ content in the gas phase. This also prevents formation of sulfide film, which can have some protection functions and facilitate adsorption of amines. Besides, the corrosion behavior can change in vapor gas phase in this case and corrosion is mainly accompanied by oxygen depolarization. This is not a mere coincidence that steel samples exposed to vapor phase above the base solution or TA-containing solution at $C_{\mathrm{H}_{2} \mathrm{~S}}=0.5 \mathrm{~g} / 1$ manifested dark brown and red corrosion products similar to rust that forms upon atmospheric steel corrosion (ferric oxides and hydroxides).

There is no doubt that a change in the solution $\mathrm{pH}$ is an important factor that influences the protection of steels by amines. The distribution diagram for $\mathrm{H}_{2} \mathrm{~S}$ acid composed on the basis of its $\mathrm{p} K_{\mathrm{a}}^{\mathrm{I}}=7.02$ and $\mathrm{p} K_{\mathrm{a}}^{\mathrm{II}}=14$ is presented in [17]. The following $\mathrm{pH}$ were selected for the studies: $3.6,6.0$ and 8.4. The content of volatile molecular form $\left[\mathrm{H}_{2} \mathrm{~S}\right]$ was $99.96,91.30$ and 4.00 mol.\%, respectively. When $\mathrm{pH}$ was increased, the corrosion rate of $08 \mathrm{ps}$ and $70 \mathrm{~S} 2 \mathrm{KhA}$ steels decreased correspondingly in gas vapor phase $\left(\mathrm{g} /\left(\mathrm{m}^{2} \cdot \mathrm{h}\right)\right): 0.455,0.43,0.188$ and $0.417,0.36,0.141$, and in liquid phase: $0.23,0.126$, 0.035 and $0.433,0.058,0.016$ for $\mathrm{pH} 3.6,6.0,8.4$ (Table 6). 
Table 5. Protective effects of amines in vapor (numerator) and liquid (denominator) phases after 10-day tests in NACE solution saturated by $0.5,1$ and $2 \mathrm{~g} / 1 \mathrm{H}_{2} \mathrm{~S}, p_{\mathrm{N}_{2}}=1 \mathrm{~atm}$.

\begin{tabular}{|c|c|c|c|c|c|c|}
\hline VCI & $\begin{array}{l}C_{\mathrm{in}}, \\
\mathrm{g} / \mathrm{l}\end{array}$ & $\begin{array}{c}C_{\mathrm{H}_{2} \mathrm{~S}}, \\
\mathrm{~g} / \mathrm{l}\end{array}$ & $\begin{array}{c}\text { St. 08ps } \\
Z, \%\end{array}$ & $\begin{array}{c}\text { St. } 70 \mathrm{~S} 2 \mathrm{KhA} \\
Z, \%\end{array}$ & $\begin{array}{c}\text { pH before } \\
\text { the test }\end{array}$ & $\begin{array}{c}\text { pH after the } \\
\text { test }\end{array}$ \\
\hline \multirow{7}{*}{ SA } & 0.5 & 2.0 & $\frac{56.5}{97.9}$ & $\frac{61.8}{98.1}$ & 4.88 & 5.04 \\
\hline & \multirow{3}{*}{1.0} & 0.5 & $\frac{-60.0}{87.6}$ & $\frac{-78.0}{86.4}$ & 6.39 & 6.43 \\
\hline & & 1.0 & $\frac{-8.6}{80.5}$ & $\frac{16.5}{97.4}$ & 6.05 & 6.25 \\
\hline & & 2.0 & $\frac{64.3}{93.3}$ & $\frac{23.7}{94.1}$ & 5.62 & 6.02 \\
\hline & & 0.5 & $\frac{60.6}{83.4}$ & $\frac{75.1}{90.4}$ & 7.48 & 10.21 \\
\hline & 2.0 & 1.0 & $\frac{63.4}{76.9}$ & $\frac{66.6}{92.4}$ & 6.69 & 7.89 \\
\hline & & 2.0 & $\frac{94.2}{97.2}$ & $\frac{98.9}{98.1}$ & 6.23 & 6.47 \\
\hline \multirow{7}{*}{ TA } & 0.5 & 2.0 & $\frac{34.0}{93.3}$ & $\frac{7.0}{98.2}$ & 4.54 & 4.70 \\
\hline & \multirow{3}{*}{1.0} & 0.5 & $\frac{-172}{76.5}$ & $\frac{-141}{86.0}$ & 6.10 & 6.26 \\
\hline & & 1.0 & $\frac{-23.0}{88.3}$ & $\frac{-25.0}{95.0}$ & 5.78 & 5.85 \\
\hline & & 2.0 & $\frac{49.6}{98.7}$ & $\underline{34.4}$ & 5.64 & 5.81 \\
\hline & \multirow{3}{*}{2.0} & 0.5 & $\frac{-131}{97.8}$ & $\frac{-32.0}{97.3}$ & 7.14 & 9.15 \\
\hline & & 1.0 & $\frac{58.0}{95.7}$ & $\frac{42.5}{98.8}$ & 6.67 & 8.95 \\
\hline & & 2.0 & $\frac{95.7}{97.5}$ & $\frac{93.4}{98.9}$ & 6.25 & 6.56 \\
\hline
\end{tabular}

Impact of $\mathrm{pH}$ on protective properties of amines is more complicated. If we compare test results for initial solution with pH 3.6 (Table 5) and 6.0 (Table 6), we will see that in the second case corrosion inhibition in the liquid phase remains at a high level $\left(Z_{\text {gas }}>\right.$ $90 \%$ ). However in gas vapor phase efficiency of protection of low-carbon steel by amines 
decreases, though TA protects $70 \mathrm{~S} 2 \mathrm{KhA}$ steel against $\mathrm{HSC}$ better than in acid environment.

Injection of $2.0 \mathrm{~g} / 1 \mathrm{SA}$ in the initial alkaline medium significantly slows down steel corrosion $\left(Z_{\text {liq }} \geq 88.9 \%\right)$. However, such $\mathrm{pH}$ increase to protect steel in gas vapor phase has negative consequences. It even leads to serious stimulation of low carbon steel corrosion in SA containing environment, whereas TA provides very weak protection $\left(Z_{\text {gas }}<30.2 \%\right)$.

Table 6. Impact of $\mathrm{pH}$ on protective effects of amines $\left(C_{\mathrm{in}}=2 \mathrm{~g} / \mathrm{l}\right)$ and steel plasticity in vapor (numerator) and liquid (denominator) phases. $C_{\mathrm{H}_{2} \mathrm{~S}}=2 \mathrm{~g} / 1, p_{\mathrm{N}_{2}}=1 \mathrm{~atm}$. Test period is 10 days.

\begin{tabular}{|c|c|c|c|}
\hline VCI & $\begin{array}{c}\text { St. 08ps } \\
Z, \%\end{array}$ & $\begin{array}{c}\text { St. } 70 \mathrm{~S} 2 \mathrm{KhA} \\
Z, \%\end{array}$ & $\begin{array}{c}\mathrm{pH} \\
\text { after the test }\end{array}$ \\
\hline \multicolumn{4}{|c|}{$\mathrm{pH} 3.6$} \\
\hline SA & $\frac{94.2}{97.2}$ & $\frac{98.9}{98.1}$ & 6.47 \\
\hline $\mathrm{TA}$ & $\frac{95.7}{97.5}$ & $\frac{93.4}{95.7}$ & 6.56 \\
\hline \multicolumn{4}{|c|}{$\mathrm{pH} 6.0$} \\
\hline SA & $\frac{51.9}{90.5}$ & $\frac{66.1}{97.4}$ & 7.29 \\
\hline $\mathrm{TA}$ & $\frac{87.4}{99.5}$ & 92.4 & 6.92 \\
\hline \multicolumn{4}{|c|}{$\mathrm{pH} 8.4$} \\
\hline SA & $\frac{-28.0}{96.6}$ & $\frac{10.6}{88.9}$ & 10.84 \\
\hline $\mathrm{TA}$ & $\frac{6.7}{96.8}$ & $\frac{30.2}{91.4}$ & 10.2 \\
\hline
\end{tabular}

Effect of VCI in wet $\mathrm{H}_{2} \mathrm{~S}$ flow deserves attention (Table 7), as this medium better determines inhibitor behavior under dynamic conditions. Tests were carried out in accordance with the procedure described earlier. The corrosion rate of St.20 was 1.19 and $1.53 \mathrm{~g} /\left(\mathrm{m}^{2} \cdot \mathrm{h}\right)$ in gas vapor phase above base solution, and 0.6 and $3.6 \mathrm{~g} /\left(\mathrm{m}^{2} \cdot \mathrm{h}\right)$ at 20 and $80^{\circ} \mathrm{C}$ in liquid phase, correspondingly. The $Z$ value of amines increased appropriately with $C_{\text {in }}$ growth. An increase in temperature up to $80^{\circ} \mathrm{C}$ deteriorated the corrosion protection properties of SA at all the $C_{\text {in }}$ studied, and those of TA at $C_{\text {in }}=0.5 \mathrm{~g} / 1$. The protective properties of TA increased to $95.0-97.4 \%$ at $C_{\text {in }}=1-2 \mathrm{~g} / 1$. The enhancement of TA effectiveness can be explained by increase of steel corrosion rate in non-inhibited media and intensification of amine volatility with an increase in temperature. In liquid phase the protective properties of amines improved at $C_{\text {in }}>1.0 \mathrm{~g} / 1$. Residual plasticity of SV08A carbon steel after 5-hour tests without VCI was 44 and 25\% in gas and liquid phase at 
$20^{\circ} \mathrm{C}$ and $33 \%$ in both phases at $80^{\circ} \mathrm{C}$. Injection of amines at $20^{\circ} \mathrm{C}$ significantly improved the ductile properties of steel wire. In some cases they amounted to $100 \%$ for both phases. In most cases, an increase in temperature caused a change in plasticity, which is similar to above mentioned impact on steel protection by amines. The concentration of $C_{\mathrm{H}_{2} \mathrm{~S}}$ (Table 7) in solutions estimated after the tests indicated that the liquid phase was saturated with $\mathrm{H}_{2} \mathrm{~S}$ to the maximum possible limit (under given conditions).

Table 7. Protective effects of amines and residual steel plasticity after 5 hours of continuous blowing by wet $\mathrm{H}_{2} \mathrm{~S}$ (preliminary deaeration for $30 \mathrm{~min}$ ) at 20 and $80^{\circ} \mathrm{C}$. The numbers in the numerator indicate the vapor phase, those in the denominator - the liquid phase.

\begin{tabular}{|c|c|c|c|c|c|c|c|}
\hline \multirow[b]{2}{*}{ VCI } & \multirow{2}{*}{$\begin{array}{l}C_{\text {in }}, \\
\text { g/l }\end{array}$} & \multicolumn{3}{|c|}{$2^{\circ} \mathrm{C}$} & \multicolumn{3}{|c|}{$8^{\circ}{ }^{\circ} \mathrm{C}$} \\
\hline & & $\begin{array}{c}\text { St. } 20 \\
Z, \%\end{array}$ & $\begin{array}{c}\text { St. SV08A } \\
\quad P, \%\end{array}$ & $C_{\mathrm{H}_{2} \mathrm{~S}}, \mathrm{mg} / \mathrm{l}$ & $\begin{array}{c}\text { St. } 20 \\
Z, \%\end{array}$ & $\begin{array}{c}\text { St. SV08A } \\
P, \%\end{array}$ & $C_{\mathrm{H}_{2} \mathrm{~S}}, \mathrm{mg} / \mathrm{l}$ \\
\hline \multirow{3}{*}{ SA } & 0.5 & $\frac{46.2}{82.3}$ & $\frac{44.0}{75.0}$ & 3400 & $\frac{12.9}{79.7}$ & $\frac{55.0}{42.0}$ & 893 \\
\hline & 1.0 & $\frac{76}{87.2}$ & $\frac{44.0}{100}$ & 3700 & $\frac{56.9}{92.7}$ & $\frac{92.0}{100}$ & 840 \\
\hline & 2.0 & $\frac{90.3}{89.0}$ & $\frac{100}{100}$ & 3400 & $\frac{85.1}{96.5}$ & $\frac{100}{100}$ & 850 \\
\hline \multirow{3}{*}{$\mathrm{TA}$} & 0.5 & $\frac{62.4}{92.6}$ & $\frac{100}{44}$ & 3315 & $\frac{5.0}{64.4}$ & $\frac{72.0}{36.0}$ & 730 \\
\hline & 1.0 & $\frac{90.3}{88.1}$ & $\frac{100}{100}$ & 3500 & $\frac{95.0}{96.2}$ & $\frac{95.0}{89.0}$ & 725 \\
\hline & 2.0 & $\frac{96.6}{98.5}$ & $\frac{100}{100}$ & 3200 & $\frac{97.4}{97.9}$ & $\frac{100}{100}$ & 740 \\
\hline
\end{tabular}

As compared to static tests, results of tests performed under dynamic conditions are closer to reality in terms of effectiveness of steel protection, especially in gas vapor phase.

The important feature of VCI inhibitors is that they are able to protect steel surface in the area of periodic wetting that is usually studied in a wheel type unit. Protective properties of amines were examined on St. 3 samples for 5 hours under such conditions (Fig. 2). The corrosion rate without a VCI and both without and with the hydrocarbon phase was $K=4.68$ and $3.5 \mathrm{~g} / \mathrm{m}^{2} \cdot \mathrm{h}$, correspondingly. The protective effect of both VCIs continued to grow along with an increase in their concentration in the wetting fluid and finally almost approached the value of $Z=90 \%$ at $C_{\text {in }}=2.0 \mathrm{~g} / 1$. Hydrocarbon phase increased $Z$ value of amines at $C_{\mathrm{in}}=0.5 \mathrm{~g} / 1$. However, at $C_{\mathrm{in}} \geq 1.0 \mathrm{~g} / \mathrm{l}$, the $Z$ value slightly decreased. This happens because hydrocarbons reduce the corrosiveness of the media approximately by $1 / 3$. Protection effectiveness of amines remains at a high level. 


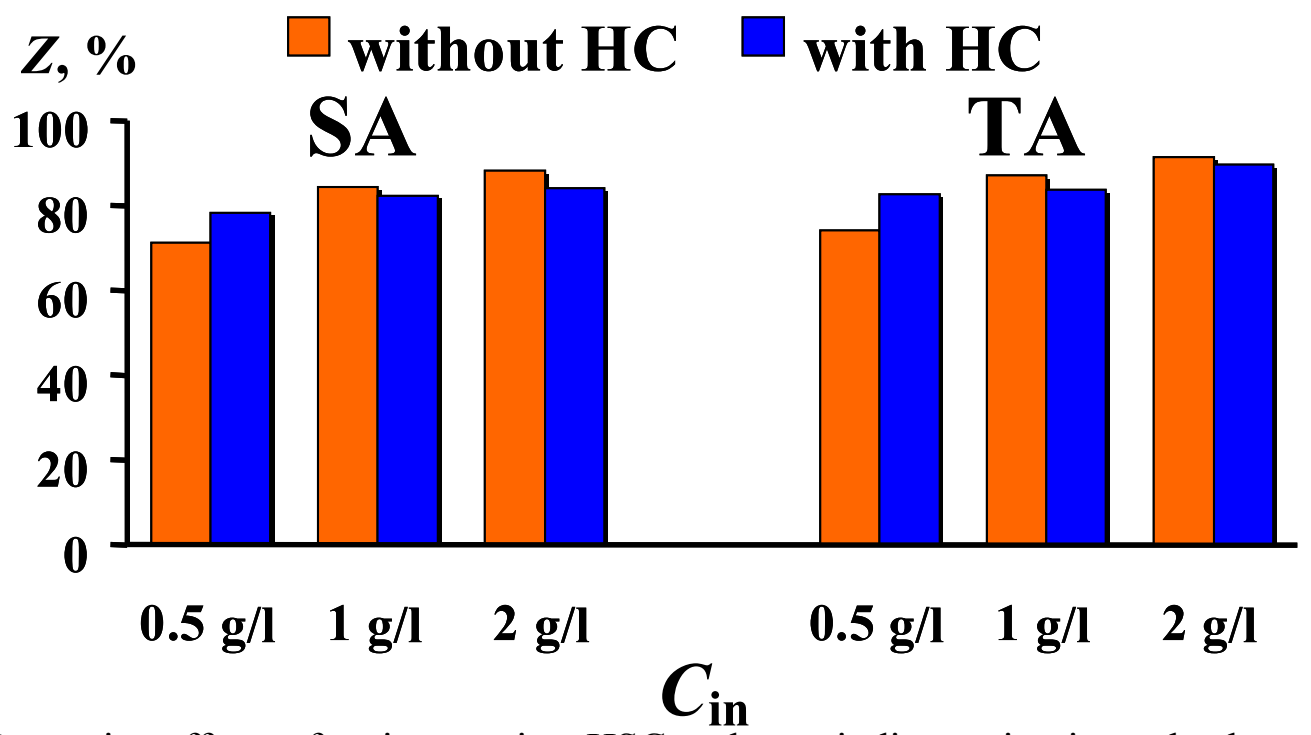

Fig. 2. Protective effects of amines against HSC under periodic wetting in a wheel-type unit with and without hydrocarbon phase, $\tau=5 \mathrm{~h}$. $C_{\mathrm{H}_{2} \mathrm{~S}}=2 \mathrm{~g} / \mathrm{l}$.

\section{Conclusions}

1. The results obtained prove a basic possibility of inhibition of steel HSC in a vapor phase by volatile amines.

2. Secondary (SA) and tertiary amines (TA) are able to ensure effective steel protection against hydrogen sulfide corrosion (HSC) in vapor phase above the solution containing $C_{\mathrm{H}_{2} \mathrm{~S}}=2 \mathrm{~g} / 1$ with $\mathrm{pH} 3.6$ providing strong protection $Z_{\mathrm{gas}}=94.2-98.9 \%$ at $C_{\mathrm{in}}=2 \mathrm{~g} / 1$.

3. The chemical compounds studied (SA and TA) effectively inhibit HSC both under periodic wetting conditions ( $Z$ up to $90 \%$ ), also in the presence of a hydrocarbon phase, and under wet $\mathrm{H}_{2} \mathrm{~S}$ flow conditions $\left(Z_{\text {gas }}=90.3-96.6 \%\right)$.

\section{References}

1. V. V.Zav'yalov, Problemy ekspluatatsionnoi nadezhnosti truboprovodov na pozdnei stadii razrabotki mestorozhdenii (Problems of pipeline operating reliability at late stages of field production), Moscow, VNIIOENG, 2005 (in Russian).

2. A. A. Gonik, Korroziya neftepromyslovogo oborudovaniya i mery ego preduprezhdeniya (Corrosion of oil field equipment and measures of its prevention), Moscow, Nedra, 1976 (in Russian).

3. N. A. Gafarov, A. A. Goncharov and V. M. Kushnarenko, Korroziya i zashchita oborudovaniya serovodorodsoderzhashchikh neftegazovykh mestorozhdeniy (Corrosion and equipment protection at hydrogen sulfide containing oil and gas fields), Moscow, Nedra, 1998 (in Russian). 
4. F. M. Mustafin, L. I. Bykov and A. G. Gumerov, Promyslovye truboprovody $i$ oborudovanie (Field pipelines and equipment), Moscow, Nedra, 2004 (in Russian).

5. V. V. Kuznetsov, G. V. Khaldeev and V. I. Kichigin, Navodorozhivanie metalla $v$ electrolitakh (Metal hydrogenation in electrolytes), Moscow, Mashinostroenie, 1993 (in Russian).

6. Yu. I. Kuznetsov and E. Ya. Lublinskii, Ingibitory dlya zashchity ot korrozii pri otstoe, khranenii i transportirovke nefti (Inhibitors for protection against corrosion during oil sedimentation, storage and transportation), Moscow, VNIIOENG, 1980 (in Russian).

7. I. L. Rozenfel'd, L. V. Frolova and V. M. Brusnikina, Soviet Scientific Reviews, Section B. Chemistry reviews, Amsterdam: OPA Ltd., 1987, 8, 115.

8. N. N. Andreev and Yu. I. Kuznetsov, Russ. Chem. Rev., 2005, 74, 685.

9. Yu. I. Kuznetsov and R. K. Vagapov, Zashchita metallov, 2000, 36, no. 5, 520 and 2002, 38, no. 3, 32 (in Russian).

10. R.K. Vagapov, L.V. Frolova and Yu.I. Kuznetsov, Zashchita metallov, 2002, 38, no. 1, 244 (in Russian).

11. S. B. Kichenko and A. B. Kichenko, Praktika protivokorrozionnoi zashchity, 2007, 43, no. 1, 12 (in Russian).

12. L. E. Tsygankova, E. G. Kuznetsova and Yu. I. Kuznetsov, Korroziya: materialy, zaschita, 2008, no. 2, 26 (in Russian).

13. N. N. Andreev and Yu. I. Kuznetsov, Russian Journal of Physical Chemistry A, 1993, no. $9,1912$.

14. N. N. Andreev and Yu. I. Kuznetsov, Int. J. Corros. Scale Inhib., 2012, Vol. 1, 16. doi: 10.17675/2305-6894-2012-1-1-016-025

15. C. Hanch and A. Leo, Correlation analysis in chemistry and biology, N.Y., J. Willey, 1981.

16. I. L. Rozenfel'd, G. G. Krimcheeva and V. R. Vezirova, Korroziya i zashchita $v$ neftyanoi promyshlennosti (Corrosion and protection in oil industry), Moscow, VNIIOENG, 1980, no. 4, 3 (in Russian).

17. R. V. Kashkovskiy, Yu. I. Kuznetsov and R. K. Vagapov, Korroziya: materialy, zaschita, 2010, no. 4, 13 (in Russian). 